\title{
You Said "Capital"? \\ Extending the Notion of Capital, Interrogating Inequalities and Dominant Powers
}

Laurent Thévenot

Unlike other economists who declare themselves indifferent to inequalities—or, like Nobel Prize winner Robert Lucas, regard the focus on them as the most "poisonous" tendency for "sound economics" 1 - it is precisely in this direction that Thomas Piketty turns his study of capital. Indeed, his work extends beyond the limits and preferred subjects of economics as a discipline and concerns the social sciences as a whole. As Piketty deals with inequalities in terms of capital assets, it is crucially important to examine the notion of capital as he uses it when he brings to light its inegalitarian distribution and expresses concern about the intergenerational transmission of inequality. He has opted for a definition of capital based on its legal ownership, its exchangeability on a market, and the monetary return on the investment that created it. Some commentators have hailed his return to a "purified" definition, removed from the proliferation of different types of capital, human and other, which they see as so many sources of confusion. Geoffrey Hodgson thus praises Piketty for having "redefined capital after 200 years of confusion," ${ }^{2}$ calling for such a purification in reaction against the definitions proposed not only by sociologists like Pierre Bourdieu or James Coleman, but also by certain economists.

\footnotetext{
This article was translated from the French by Richard Nice and edited by Chloe Morgan and Nicolas Barreyre.

1. Robert E. Lucas, "The Industrial Revolution: Past and Future (2003 Annual Report Essay)," The Region, May 2004, https://www.minneapolisfed.org/publications_papers/ pub_display.cfm?id=3333.

2. Geoffrey M. Hodgson, "Piketty Has Redefined Capital, after 200 Years of Confusion," The Conversation, April 22, 2014, http://theconversation.com/piketty-has-redefined-capitalafter-200-years-of-confusion-25770.
} 
Adam Smith himself extended capital to include the physical assets purchased and used in production and, long before Gary Becker, suggested that labor as a productive resource could also be regarded as "capital." ${ }^{3}$ By contrast, other commentators have criticized Piketty for this reduction, in particular those who make reference to the kinds of capital deployed in the work of Pierre Bourdieu. ${ }^{4}$ The plurality of the kinds of capital is thus being debated. Here, however, I want to move beyond this disputed multiplicity to reflect on the concept of capital itself and discuss Piketty's use of it. By examining the political genesis of "human" and "intellectual" capital, followed by other kinds of capital variables used to evaluate different types of inequalities, we can shift attention toward the embedding of capital in a mode of coordination among actors, which is the precondition for its valorization and differs from one kind of capital to another. This displacement leads to a critical reflection on Piketty's decision to conflate a set of capital assets with very different uses by considering them solely in terms of their valuation in market terms. The embedding of each kind of capital in the mode of coordination required for its valorization leads to a clearer understanding of the powers associated with these kinds of capital, their claims to legitimacy in spite of the inequalities they cause, and the dominations they exert. I will thus consider in turn three fundamental elements of Piketty's work: the various kinds of capital, inequality (whether legitimate or not), and the policies of a social state.

\section{“Human" Capital, "Intellectual" Capital: First Extensions}

The history of the extended category of capital is shorter than the period covered by the cumulated data that Piketty offers us, for it begins in the early twentieth century. It is important here because the category is embedded in a political interrogation of inequality that drives Piketty as much as his critics. The types of inequality considered vary substantially over this period, as does the political perspective in which they were placed. The conceptions of capital and inequality that Piketty foregrounds therefore need to be resituated in a broader historical movement.

The construction of a notion of human capital predates the writings of Becker and Coleman, as well as those of Bourdieu-three authors often cited when Capital in the Twenty-First Century is discussed. The economist Irving Fisher expanded the concept of capital to encompass everything that provided a revenue stream; he included human beings as "human capital" and set this extension in a policy emphasizing eugenicism and public health, conceived as a contribution to the good of the

3. Hodgson, "What Is Capital? Economists and Sociologists Have Changed its Meaning: Should it Be Changed Back?," Cambridge Journal of Economics 38, no. 5 (2014): 1063-86. 4. These critiques range from the virulent to the more moderate. For the former kind, see: Geoffroy de Lagasnerie, "Le manifeste inégalitaire de Thomas Piketty," Libération, October 17, 2013; and Didier Eribon, "La gauche contre elle-même," Le Monde, May 10, 2014. For the latter, see Alexis Spire, "Capital, Social Reproduction, and the Rise of Inequality," Annales HSS (English Version) 70, no. 1 (2015): 57-64. 
community. ${ }^{5}$ Demographic and statistical works on the measurement of inequality in France bore the mark of this influence until the 1950s, when the bedrock of eugenicist policy gave way to a "selection of the best" implemented through the school system. "Human capital" continued to be envisaged from the point of view of the national community, not the individual as was later the case. Since schooling was supposed to reveal an inequality of capacities, the very low proportion of working-class children in higher levels of education was criticized. To interpret this, the demographer Alain Girard introduced the concept of "intellectual capital," which, "developed over successive generations," ensured the success of children from bourgeois families. ${ }^{7}$ He reflected on the growth of this capital from generation to generation, based on domestic relations, without finding this familial transmission illegitimate.

This is quite the opposite of the critical approach to intellectual capital constructed by Bourdieu and Jean-Claude Passeron in The Inheritors. ${ }^{8}$ In 1966, Bourdieu assembled a collective work, Le partage des bénéfices, with Alain Darbel from the National Institute of Statistics and Economic Studies (INSEE). ${ }^{9}$ This volume brought together sociologists, economists, demographers, and statisticians, and marked a turning point in the diversification of the notion of capital and its measurement. In it, Bourdieu draws extensively on the statistics furnished by fellow contributors Girard and Henri Bastide, but does so in order to argue that the school system "provides the appearance of legitimation to social inequality and gives its sanction to cultural inheritance." 10 The work brings together, not without some discordances and misunderstandings, an extended conception of capital that was to mark both the sociology inspired by Bourdieu and the official statistics developed in France to provide data for policies "combatting inequality," as they were called in the documents of the state planning agency. It should be noted that this kind of "social state," equipped with categories and statistical data, ${ }^{11}$ resembles the one that Piketty calls for in the fourth part of his work when he draws up a program for the twenty-first century based on political measures. ${ }^{12}$

5. Irving Fisher, The Nature of Capital and Income (New York: Macmillan, 1906). See Annie Cot, "Le gène et l'intérêt, l'anamorphose d'Irving Fisher," Histoire de la pensée économique. Économies et sociétés 11, no. 4 (1989): 89-107.

6. Alain Girard, La réussite sociale en France, ses caractères, ses lois, ses effets (Paris: PuF, 1961), 21.

7. Ibid., 350; Laurent Thévenot, "La politique des statistiques: les origines sociales des enquêtes de mobilité sociale," Annales ESC 45, no. 6 (1990): 1275-300.

8. Pierre Bourdieu and Jean-Claude Passeron, The Inheritors: French Students and Their Relation to Culture, trans. Richard Nice (Chicago: University of Chicago Press, 1979).

9. Darras [Pierre Bourdieu et al.], ed., Le partage des bénéfices. Expansion et inégalités en France (Paris: Éd. de Minuit), 1966.

10. Pierre Bourdieu, "La transmission de l'héritage culturel," in Darras, Le partage, 397. 11. Alain Desrosières, The Politics of Large Numbers. A History of Statistical Reasoning, trans. Camille Naish (Cambridge: Harvard University Press, 1998).

12. Thomas Piketty, Capital in the Twenty-First Century, trans. Arthur Goldhammer (Cambridge/London: Harvard University Press, 2014), 477 and 629, n. 9. Piketty rightly prefers the term "social state" to "welfare state." 


\section{As Many Types of Capital Variable as Types of Inequality}

This glance at the early extensions of the notion of capital brings out the structural linkage between the diversification of the concept and that of the inequalities targeted by specific policies. This link is also the one that holds the parts of Capital in the Twenty-First Century together. To situate Piketty's choices, we must therefore replace them in the history of the variations of the triad capital-inequality-policy and trace the development of the notions related to capital that have overtaken those invoked above. Given the place occupied in this history by the development of Bourdieusian sociology, discussion here will be limited to the French context in which it emerged. The analysis will be based on conclusions drawn from an empirical study of the modifications and uses, over the last fifty years, of INSEE's Formation et qualification professionnelle (training and occupational skills) survey, a major statistical source for the study of inequality and remedial policies in France. ${ }^{13}$ This study makes it possible to identify four types of capital variable, which are related to the notion of capital and whose relative importance varies over the period. Each of these characterizes a mark that is imprinted on a person by his or her past of learning and investment and enters into a valuation-which may be negative in the case of devaluation. As shall be seen, the displacements of the variable defining a kind of capital are accompanied by corresponding displacements in the type of inequality targeted by public policies.

The first variable designates the mark of a social origin identified by the occupation of an individual's parents' and characterizes a kind of capital transmitted from the previous generation. The earlier manifestations of this concept have been mentioned above; since the 1960s, it has exclusively been envisaged in terms of its negative effects via the family or the school system. However, this negative appreciation stems from two underlying political constructions that inform distinct sociological schools: a civic aim of combating inequality in social conditions, which underpins Bourdieusian sociology; and a liberal aim of equalizing individual opportunity-as presented in the works of James Coleman and Raymond Boudon-, which lies at the heart of the meritocracy espoused by Piketty. ${ }^{14}$

13. Without common measure with the work accomplished by Piketty, this historical and empirical work is also on another level as regards the use of statistical data: it collects and analyzes data on the collection and analysis of statistical data, based on the questionnaires, processing tools, theories mobilized, and commentaries that feed into the articles that use the primary data. This orientation cannot be reduced to social constructivism. See: Olivier Monso and Laurent Thévenot, "Les questionnements sur la société française pendant quarante ans d'enquêtes Formation et Qualification Professionnelle," Économie et statistique 431/432 (2010): 13-36; Thévenot, "Conventions for Measuring and Questioning Policies: The Case of 50 Years of Policy Evaluations through a Statistical Survey," Historical Social Research 36, no. 4 (2011): 192-217.

14. The civic order of value, like the industrial order or the order of opinion mentioned below, belongs to the grammar of plural worths: see Luc Boltanski and Laurent Thévenot, On Justification: Economies of Worth, trans. Catherine Porter (Princeton: Princeton University Press, 2006). On the liberal grammar, see the following articles by Laurent 
The second type of capital variable, "occupational qualification," became increasingly important in the 1970s. It is most often measured in terms of qualifications and is acquired through schooling and continuing education. It extends the previous definition of human capital since it is envisaged from the viewpoint of the state and its educational policies, which are oriented toward the valorization of these skills in production. "Capital for a nation," as the political demographer Alfred Sauvy called it, shifted from "human capital" to "occupational qualification," or "skill." This capital variable forms part of the enterprise of state planning, which is aimed at industrial development and intended to orient the educational system toward the "needs of production." This implies the creation of national accounting frameworks that measure the training, assignment, and movements of the laborforce according to these skills.

This policy is entirely distinct from the one based on the third type of capital variable, which also bears the name "human capital" but which is defined quite differently. Deployed in the writings of Gary Becker and Jacob Mincer, ${ }^{15}$ it began to appear in the evaluation of public policies in the late 1970s, with the development of education economics. It really took off ten years later, when the economic approach and European policies on "competences" and their "activation"-for which the individual is seen as responsible-took precedence over a critical sociology of social inequality and its reproduction by social origin. "Human capital" is subsequently understood as the result of an individual accumulation of training. ${ }^{16}$ This capital takes its place in an investment plan calculated on the basis of the remuneration expected on a market.

The fourth type of capital variable appeared still more recently, in the debates arising from the unequal treatment that may be related to what is called a cultural or ethnic origin. This variable does not have an established name, so intense is the debate about how it conflicts with the first type of capital variable, the mark of a social origin. Even the legitimacy of measuring it has been the subject of heated argument. This competition has revealed the kinship between these two capital variables, which form part of the same conceptual family of capital. Like the first type, this last type of capital variable is involved in positive valuations

Thévenot: “Autorités à l'épreuve de la critique. Jusqu'aux oppressions du gouvernement par l'objectif," in Le tournant de la théorie critique, ed. Bruno Frère (Paris: Desclée de Brouwer, 2015): 216-35; "Powers and Oppressions from the Perspective of the Sociology of Engagements: A Comparison with Bourdieu's and Dewey's Critical Approaches to Practical Activities," Irish Journal of Sociology 19, no. 1 (2011): 35-67.

15. Gary Becker, Human Capital: A Theoretical and Empirical Analysis with Special Reference to Education (New York: National Bureau of Economic Research, 1964); Jacob Mincer, "Investment in Human Capital and Personal Income Distribution," Journal of Political Economy 66, no. 4 (1958): 281-302.

16. The measurement of human capital raises difficulties that reveal the effort needed to make investments commensurable. It implies integrating occupational training and initial education, and even treating it as a time-equivalent in order to make it a scalar variable relatable to income, which is seen as the return on the investment. See Monso and Thévenot, "Les questionnements." 
and negative disqualifications. These disqualifications are unjustified with regard to a valorization of human capital. The valorization of a cultural or ethnic mark is covered by the positive term "empowerment," and is based on a liberal construction open to multiculturalism and valuing a freely chosen individual identity. ${ }^{17}$ This construction and the rights associated with it-the scope of which has been expanded by the European Union - are the foundation of challenges to discriminatory and unequal treatment. ${ }^{18}$

\section{As Many Types of Capital Variable as Modes of Coordination Enabling their Valorization}

What light does this history of the metamorphoses of capital following-and competing with-Bourdieu's conceptualization of cultural capital shed on Piketty's work? The diversification of capital variables does not simply add other types of capital whose absence from Capital in the Twenty-First Century may be regretted. It brings to light the irreducible heterogeneity of the ways in which people are able to "capitalize" their assets and valorize their capital, a diversity that I characterize as "modes of coordination" with others, with oneself, and with the surrounding world. There is no "return on investment" without an appropriate mode of coordination, determining a particular mode of valorization of capital.

This link is evident for "social capital" as Bourdieu understands it, since it stems from "the possession of a durable network of relationships." ${ }^{19}$ Likewise, "cultural capital" clearly goes hand in hand with a connection to others that is of a domestic order and requires personalized relationships with people and with cultural objects, deployed in the framework of the family or the school. ${ }^{20}$ Distinguishing "the three states of cultural capital" from the approach taken by human-capital economists to returns on educational investment, Bourdieu criticizes their use of a measurement that "takes account only of monetary investments and profits, or

17. It should be noted that in the United States, under the influence of a "liberal" political construction, proposals to add a new type of capital may make reference to Bourdieu while being based more in a perspective of "empowerment" than the critique of powers of domination. For example, Catherine Hakim sets out to identify "erotic capital" as a mode of empowerment that might counterbalance the lack of other types (economic, cultural, and social) available to the most disadvantaged. This capital has, in her view, been overlooked by the elites because they cannot monopolize it: Catherine Hakim, Erotic Capital: The Power of Attraction in the Boardroom and the Bedroom (New York: Basic Books, 2011), 17.

18. Joan Stavo-Debauge, "Mobilising Statistical Powers for Action against Discrimination: The Case of the United Kingdom," International Social Science Journal 57, no. 183 (2005): $43-55$.

19. Pierre Bourdieu, "The Forms of Capital," trans. Richard Nice, in Handbook of Theory and Research for the Sociology of Education, ed. John G. Richardson (New York: Greenwood Press, 1986), 241-58. The italics are Bourdieu's. of worth mentioned below, see Boltanski and Thévenot, On Justification. 
those directly convertible into money" and misses "the best hidden and socially most determinant educational investment, namely, the domestic transmission of cultural capital." ${ }^{21}$ Such a mode of investment, transmission, and valorization is indeed opposed to the calculation and the mode of coordination that valorizes market worth and is presupposed by the economistic definition of human capital. This in turn differs from occupational qualification capital, which is invested and valorized in a collective framework of training-employment relations consecrated by occupational classifications, through a mode of coordination governed by the worth of industrial efficiency.

Once the link between the type of capital and the mode of coordination ensuring its investment and valorization is made apparent, the question becomes whether scholars who use the notion of capital take it into consideration. ${ }^{22}$ Piketty does not take account of any of the extensions that I have considered here, and does not discuss those proposed by Bourdieu. "Cultural capital" is mentioned a single time in Capital in the Twenty-First Century, ${ }^{23}$ and Bourdieu's name appears only once, with reference to The Inheritors, in a discussion of educational institutions' influence on social mobility contained in the chapter concerning a social state for the twenty-first century. ${ }^{24}$ Yet this discussion is, as has been seen, at the heart of the progressive development of the notions of "intellectual capital" and "cultural capital." Piketty even excludes the extension of a human capital integrated into economic market calculation, on the grounds that this capital cannot be formalized by a legal ownership that can be traded and exchanged on a market, except in the case of the only true form of human capital-that which results from slavery. The reason for Piketty's choices is clear. Since it is a matter of accounting, he opts for a strictly monetary definition that can establish the form of equivalence required for the large-scale chronological and transnational comparisons that he so masterfully makes.

Here we touch on the question of commensurability, an issue that is currently seeing its practices and problematics dismantled by a thriving sociology of quantification. ${ }^{25}$ Extending the analysis of forms of equivalence and their conventions,

\section{Bourdieu, "The Forms of Capital," 243-44.}

22. Does the concept of the field enable this link to be taken into account in Bourdieu's sociology of types of capital? The hierarchy of the types of capital does indeed vary according to the fields in which they are embedded, fields that have their own logics and some autonomy, and in which the actors get caught up in the game (illusio) with unequal assets. But the reference to a very extensive conception of the market makes it impossible to distinguish the capacity conditions for valorization of the various types of capital.

23. Piketty, Capital, 631, n. 21.

24. Ibid., 486.

25. Theodore M. Porter, Trust in Numbers: The Pursuit of Objectivity in Science and Public Life (Princeton: Princeton University Press, 1995); Wendy Nelson Espeland and Mitchell L. Stevens, "Commensuration as a Social Process," Annual Review of Sociology 24 (1998): 313-43; Alain Desrosières, "How Real are Statistics? Four Possible Attitudes," Social Research 68, no. 2 (2001): 339-55; Marion Fourcade, "Cents and Sensibility: Economic Valuation and the Nature of 'Nature," American Journal of Sociology 116, no. 6 (2011): 
this research draws attention to the operations and effects of common measurement. Two disciplines are particularly concerned: economics and law. Law often appeals to economics for measurements, especially when there is a need to assess damages on capital goods. Economics likewise appeals to law, as in the legal definition of capital adopted by Piketty. In this case, the ambition and quality of Piketty's work, along with his claim to be using an approach drawn from political economy, invite us to revisit the operation of establishing a common measurement. The embedding of each type of capital in a specific mode of coordination for its investment and valorization makes it possible to distinguish what the common measure chosen by Piketty excludes and what it conflates.

The potential realization of capital in a value on a market, which allows commensurability through a price, conceals important differences in modes of investment and valorization. ${ }^{26}$ Piketty accepts a deliberate confusion between "capital" and the very extensive notion of "wealth." In his explanation of his terminology, he indicates that he includes forms of wealth such as land and natural resources, with which humans have been endowed without having to accumulate them, within capital. ${ }^{27} \mathrm{He}$ also points out that he merges stores of value and factors of production-two very different uses of forms of capital related to their intrinsic properties-because of the porous nature of the boundaries between the two. These assimilations prevent him from bringing to light major differences between "economic" forms of capital which, though all potentially subject to evaluation and commensuration in accounting terms, lend themselves to off-market valorizations through very varied modes of coordination.

The possibility of reducing them to a monetary valuation should not prevent one from taking account of profound incommensurabilities among the modes of coordination that determine an off-market valorization of these forms of "wealth." This is particularly clear in the case of the goods and forms of capital attached to the environmental sphere, ${ }^{28}$ a question that Piketty only envisages in terms of the degradation of "natural capital," a type of capital that he includes in his aggregated measurement of wealth/capital. ${ }^{29}$ Yet an ecological relation to the environment and to the value of biodiversity—along with a more traditional attachment to nature

1721-77; Laura Centemeri, "The Contribution of the Sociology of Quantification to a Discussion of Objectivity in Economics," in Facts, Values and Objectivity in Economics, ed. José Castro Caldas and Vítor Neves (London: Routledge, 2012), 110-25; Centemeri, "Reframing Problems of Incommensurability in Environmental Conflicts through Pragmatic Sociology: From Value Pluralism to the Plurality of Modes of Engagement with the Environment," Environmental Values 24 (2015): 299-320.

26. In the same sense, Edward Fullbrook criticizes Piketty for maintaining the confusion, in various passages in his work, between capital as an object with intrinsic properties - amenable to certain uses—and capital measured by its price, which depends on interaction with other actors in a market. Fullbrook, "Capital and Capital: The Second Most Fundamental Confusion," Real-World Economics Review 69 (2014): 149-60. 27. Piketty, Capital, 47.

28. Laura Centemeri, "Retour à Seveso. La complexité morale et politique du dommage 
and its cultivation, capitalized with the aid of domestic care for a territory-belongs to specific modes of relation to the earth, to others, and to the self that are conducive to investments and their valorization, quite distinct from the market relation and not reducible to an asset line on a balance sheet. Nevertheless, they do not remain external to contemporary capitalism, whether they are affected by it or are integrated into it as part of the composite value chains of agro-industrial production.

\section{Forms of Capital, Powers, Legitimacy, and Domination: What Policies for What Inequalities?}

In the policies he proposes, Piketty envisages economic capital only at the stage of its taxation, in order to modify its distribution. Since he endorses this political aim, it is regrettable that he does not extend his examination to the legitimacy granted to certain inequalities-legitimate inequalities are excluded from the scope of his egalitarian policies. Starting from the heterogeneity of capital and of the modes of coordination required to valorize it, the analysis could be opened up to consider the plurality of inequalities that are sometimes regarded as legitimate and sometimes not, inequalities that are the targets of "remedial" or "liberatory" policies. ${ }^{30}$ It could also go on to examine the powers of domination buttressed by capital, echoing not only the work of Karl Marx but also that of Bourdieu, who saw the expanded definition of capital as an extension of the analysis of power based on resources of symbolic domination.

Beginning with the diversification of the notions of capital, an analysis based on the forms, modes, and infrastructures of coordination makes it possible to broaden our understanding of domination. ${ }^{31}$ The model of orders of worth deals specifically with questions of legitimacy and power. ${ }^{32}$ Worths are not only capacities

30. The Social Inequalities Committee of the Seventh French National Plan recommended "subordinating economic objectives to objectives relating to the reduction of inequality": Jacques Méraud, Rapport de la Commission Inégalités sociales (Paris: La Documentation française, 1975). In contrast, the Committee for the Liberation of French Growth considered that "the scandal lies in poverty more than in wealth, in injustices more than in inequality": Jacques Attali, Rapport de la Commission pour la libération de la croissance française: 300 décisions pour changer la France (Paris: La Documentation française, 2008).

31. Laurent Thévenot, "Conventions of Co-ordination and the Framing of Uncertainty," in Intersubjectivity in Economics: Agents and Structures, ed. Edward Fullbrook (London/ New York: Routledge, 2002), 181-97; Thévenot, "Powers and Oppressions"; Thévenot, "Autorités à l'épreuve," 216-35; Thévenot, "Certifying the World: Power Infrastructures and Practices in Economies of Conventional Forms," in Re-Imagining Economic Sociology, ed. Patrik Aspers and Nigel Dodd (Oxford: Oxford University Press, 2015), 195-223. 32. Luc Boltanski and Laurent Thévenot, Les économies de la grandeur (Paris: PUF, 1987) This work gives an account of the relationship between investment in a particular "worth" (grandeur) and the mode of coordination that ensures its valorization. Outlining a generalized economy of capacities termed "worths," the analysis does not claim to cover all forms of capacity, still less of capital. It is only concerned with those that stake a claim to legitimacy. 
to do things alongside others, but also to coordinate with them according to modalities and materialities that differ from one order of worth to another. The market, industrial, civic, and domestic orders of worth have already been mentioned. The states of those who are "worthy" in these orders enter into modes of coordination, which they in turn help to maintain. These dominant positions in terms of the mode of coordination give those who hold them power to "make people do things." Inequality of capacities thus seriously conflicts with a demand for equality and the question of its legitimacy arises. Piketty himself addresses this in his introduction, citing the second part of article 1 of the Declaration of the Rights of Man and the Citizen of 1789, which, after proclaiming that "men are born and remain free and equal in rights," adds that "social distinctions can be based only on common utility." The tension between these two parts of article 1 is central to the analysis of worths, for inequalities of worth provoke a sense of injustice with regard to the principle of an equal or common humanity. ${ }^{33}$ The quest to legitimize these inequalities, aimed at calming this tension, requires them to lay claim to a "common utility." More precisely, worth claims to belong to a mode of coordination that maintains a common good and is thus beneficial for all. In practice, analyzing this quest in no way implies that this legitimacy is regarded as established, as is the case in political discourses that refer to "legitimate inequalities." 34 On the contrary, it induces vigilance concerning this claim and the powers that stem from it.

The play of a coordination regarded as legitimate, allowing unequal states of worth, makes it possible to "make people do things" without even resorting to a hierarchy of subordination. Such a power of coordination tends to be strategically captured for individual profits, or profits restricted to very limited elites in dominant positions. In his discussion of the salaries of "supermanagers," which he relates to finance capital, Piketty justly describes this capture, which does not derive solely from legal ownership of economic capital under its initial definition. ${ }^{35} \mathrm{He}$ thus addresses the question of legitimacy through the critique of inequalities (of capital or in "supermanager" wages) that he sees as illegitimate, in relation to others which he considers legitimate (in the remuneration of labor). His meritocratic position is much debated in France. ${ }^{36}$

By tracing the emergence and the changing weights of the different types of capital variable and the inequalities they induce, I have identified the privileged links that each has with a type of policy. Policies and institutions contribute to the recognition, consolidation, or weakening of the various types of capital and their valorization. Noting the absence over the long term of economic mechanisms capable of regulating the capital/income ratio, Piketty stresses the role that the policies of a social state can play, but limits himself to those that operate through taxation.

33. Ibid.; Boltanski and Thévenot, On Justification.

34. In France in the 1990s, these discourses invoked John Rawls's theory of justice and sometimes Boltanski and Thévenot, On Justification.

35. Piketty, Capital, 265.

36. See in particular de Lagasnerie, "Le manifeste"; Eribon, "La gauche." 
However, political action also takes place through waves of criticism and protest that challenge the relative legitimacy of the types of capital variable and the forms of authority. ${ }^{37}$ The capitalist system is not a political community subject to the quest for legitimacy, and a number of the powers on which it is based clearly lie outside that quest. The fact nevertheless remains that the legitimation of valorizations holds a significant place in organizations that form part of the system. ${ }^{38}$

To explain the variations in the capital/income ratio, Piketty mentions major external shocks, especially wars, which lead to a massive destruction of economic capital. But such destruction is largely internal to the course of capitalism, as Joseph Schumpeter emphasized. This movement is itself a cause of violence and war. The distinction between types of capital, whether newly valorized or destined for destruction, is needed to account for the internal tensions and metamorphoses of capitalism over the long term. Is the equivalence Piketty constructs to draw up his long series of data not bought at too high a price if it does not take account of these distinctions? Within the aggregate capital category that Piketty constructs, the destruction of whole segments of industrial capital invested in productive organizations and the loss of its dominant position in the so-called Fordist configuration have accompanied the rise of a quite distinct type of capital, termed financial capital. The valorization of this capital is based on a mode of coordination whose very short-term temporality and global range are quite different from the properties of industrial coordination. Although designated "market capital," this mode also differs from coordination through competition on a market in conventional goods, implying an entirely different mode of coordination through opinion and speculative beliefs. These changes in the dominant type of economic capital are accompanied by waves of destruction or devaluation of types of capital not taken into account in national accounting, such as occupational qualification or the cultural and/or ethnic capital that is undermined by industrial delocalization and migration.

Compared with the neoclassical economists, Piketty stands out admirably for his call to situate economics among the other social sciences (while preferring, in this book, to refer to classic literary texts ...). Taking the author at his word, I have not sought to advance another discipline-specific approach, but to explore some fundamental and common questions that cut across disciplinary borders. ${ }^{39}$ The extended notion of "capital" is clearly as important in sociology as in economics, creating interrelations between investment behaviors, relationships required for its

37. Thévenot, "Autorités à l'épreuve."

38. In this way, the movement of orders of worth, their critique, and their creation, is part of the "spirit of capitalism": see Luc Boltanski and Ève Chiapello, The Nerw Spirit of Capitalism, trans. Gregory Elliott (London: Verso, 2005).

39. Among institutionalist currents, and especially in France, the school of regulation and the economics of conventions have been working since the $1970 \mathrm{~s}$ and $80 \mathrm{~s}$ to develop and implement the project of linking economics more closely to the other social sciences. The conventions approach considers shared, cross-disciplinary questions such as value and modes of coordination. 
valorization, and powers that claim legitimacy. Among notions such as "resource" or "power," which are used very loosely, those related to capital do not merely specify capacities. They also imply an engagement, since each of them applies the stamp of a past-imprinted in the investment-to the present and the future. Piketty attaches great importance to this feature and is concerned to see the malign weight of the past imposed on labor by economic capital extending itself into the present and future.

Market coordination and valorizations through prices occupy a central place in economics on account of monetary equivalence. However, by retracing the diversification of the types of capital and distinguishing the embedding of each of them in a mode of coordination required for its valorization, it becomes possible to bring out other valuations. Their diversity, concealed by monetary equivalence, makes it impossible to distinguish the upheaval in their respective weights, which gives rise to domination and destruction in ways that the unequal distribution of economic capital alone is not sufficient to reveal. 